\section{Research Committee}

Council Members: Drs M. Aveline, P. Bowden, Professor J. C. Gunn, Drs J. Jancar, J. Leff, D. A. Primrose, Professor K. Rawnsley, Drs R. A. Robinson, P. Sainsbury, Professor A. C. P. Sims (Chairman). (Secretary: Dr Sheila Mann.)

Collegiate Trainees Committee: Dr P. Thomas

Non-Council Co-opted Members: Drs P. Ashurst, B. Barra- clough, K. Bergmann, M. Crowe, C. P. Freeman, E. Johnstone, M. MacCulloch, R. Maggs, D. H. Malan, Professor H. G. Morgan, Drs D. Richter, G. Szmukler, Professor J. P. Watson.

Observers: Drs K. Levy (MRC), J. Pippard (Research Project), Vacancy (DHSS).

\title{
Irish Division: Annual Meeting
}

The Annual Meeting of the Irish Division took place in St Brendan's Hospital, Dublin, on 17 October 1980. The clinical programme consisted of four papers on the theme of 'Therapies'. Professor Linford Rees's paper centred on the psychopharmacology of the antidepressants and the minor and major tranquillisers. He also referred to exciting new trends in drug development. Professor Tilleard-Cole presented a detailed account of ECT and frontal leucotomy and traced the history of the latter from its beginning to the present day advances. Mr Brian Glanville, of the Department of Psychology, St Brendan's Hospital, emphasized the importance of behavioural therapy in modern psychiatry. Finally, Dr John Marks explored the possible advances that psychiatry might make in the next few decades. A panel discussion took place at the end of the meeting and provided lively discussion on all aspects of the symposium.

The Business Meeting was informed by the Chairman, Professor T. Lynch, that plans were well advanced for the Post-American Psychiatric Association Meeting in Dublin, scheduled for May 1982. The meeting then addressed itself to the Republic of Ireland's new Mental Health Services Bill. Various aspects of the Bill evoked critical comment. Particular criticism was directed to the fact that much of the Bill was devoted to the compulsory detention of patients who represent only a tiny minority of psychiatric admissions, while scant reference is made for the need to determine minimum standards of care, staffing and facilities for our Psychiatric Services in general. Other aspects of the Bill that were critically appraised were the escort provisions, composition of the Review Tribunals and the lack of provisions in regard to voluntary admissions. The Executive have prepared a submission on the new Bill and look forward to an opportunity to discuss this with the Minister of Health in due course.

It is hoped that the next Quarterly Meeting of the Irish Division will take place in early April 1981.

David Shanley Honorary Secretary

\section{Trainees' Session}

A session of trainees' papers on research topics is being organized as part of the programme for the Annual Meeting in London in July 1981.

Trainees and young psychiatrists (below the rank of consultant) are invited to give a ten-minute paper on some linvestigation which they have or are in the process of undertaking.

It may be a clinical observation; experimental clinical or

\section{Examinations-Spring 1981}

The next MRCPsych Examinations will take place on the following dates:

Preliminary Test-18 March 1981. (Closing date for receipt of entries-11 February.)

Membership Examination-13 May and 18 to 21 May

1981. (Closing date for receipt of entries-8 April.)

The entry fees are $£ 40$ and $£ 65$ respectively. Details and entry forms are available from the Examinations Secretary at the College. laboratory research; a clinical trial of a new drug; a variant of existing therapy; or a genetic or epidemiological study.

Please let us have a title and an abstract (250 words maximum) by early May 1981 and get in touch with Jane Boyce at the College address if you have any queries.

Alan poole John Crammer on behalf of the Programmes and Meetings Committee

\section{New Year Honours, 1981}

Knight Bachelor: Desmond Arthur Pond, Professor of Psychiatry, The London Hospital, and President of the Royal College of Psychiatrists.

\section{Laughlin Prizewinner}

At the recent Membership Examination held in November, the Laughlin Prize was awarded to Dr Susan Janet Cope. 